JACEK WILLECKI

Biblioteka Politechniki Poznańskiej

Oddział Informacji Naukowej

e-mail: jacek.willecki@put.poznan.pl

\title{
AKTYWNOŚĆ PROROZWOJOWA BIBLIOTEK AKADEMICKICH ZWIĄZANA Z DZIAŁANIAMI \\ NA RZECZ NAUKI I UPOWSZECHNIANIEM NAUKI, FINANSOWANA ZE ŚRODKÓW MINISTERSTWA NAUKI I SZKOLNICTWA WYŻSZEGO W LATACH 2010-2015
}

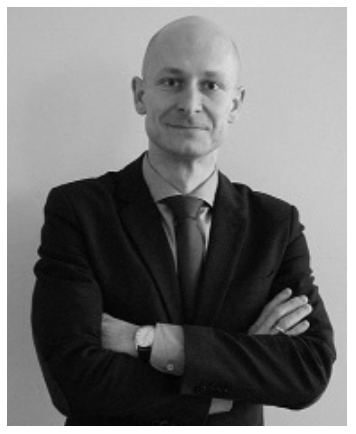

Jacek Willecki, dr inż., pracuje na stanowisku starszego specjalisty do spraw projektów w Oddziale Informacji Naukowej Biblioteki Politechniki Poznańskiej. Zajmuje się koordynowaniem projektów sektora szkolnictwa wyższego, finansowanych ze źródeł zewnętrznych, w tym realizowanych przez biblioteki uniwersyteckie. Ostatnia publikacja autora, dotycząca potencjalnych możliwości wsparcia projektów bibliotecznych ze środków krajowych i zagranicznych, to Developmental projects of university libraries providing access to scientific e-resources financed from national and eu funds „Puls Uczelni" 2016, nr 10.

SŁOWA KLUCZOWE: Aktywność prorozwojowa bibliotek. Upowszechnianie nauki przez biblioteki. Finansowanie rozwoju bibliotek szkół wyższych. Działalność bibliotek w latach 2010-2015.

ABSTRAKT: Teza/cel artykułu - celem artykułu jest określenie obszarów działalności prorozwojowej bibliotek akademickich związanych z zadaniami dotyczącymi nauki i upowszechniania nauki, finansowanymi ze środków Ministerstwa Nauki i Szkolnictwa Wyższego, a także określenie wysokości środków pozyskanych przez biblioteki szkół wyższych uczelni publicznych i niepublicznych, z uwzględnieniem środków przeznaczonych na rozwój e-zasobów z tego Ministerstwa oraz wskazanie liczby bibliotek otrzymujących wsparcie prorozwojowe na przedmiotową działalność. Metody badań - zastosowano metodę analizy i syntezy 
komunikatów i wykazów ministerialnych zawierających dane dotyczące środków finansowych przyznanych na działalność wspomagającą badania i upowszechniającą naukę. Wyniki i wnioski - Przeprowadzone badania wykazały aktywność bibliotek akademickich w piętnastu obszarach ich działalności, pozwoliły na identyfikację struktury otrzymanych środków, a także wskazały typy uczelni publicznych, które cechują się dużą skutecznością w pozyskiwaniu środków na działania dotyczące upowszechniania nauki w latach 2010-2015.

\section{MINISTERSTWO NAUKI I SZKOLNICTWA WYŻSZEGO JAKO DONATOR ŚRODKÓW WSPIERAJĄCYCH BIBLIOTEKI UCZELNIANE}

Biblioteki akademickie zajmują istotne miejsce w strukturach uczelni wyższych, odpowiadając m.in. za gromadzenie, przetwarzanie i udostępnianie zasobów naukowych środowisku akademickiemu, jak również bliższemu i dalszemu otoczeniu społecznemu i gospodarczemu. Różnorodność zbiorów bibliotecznych, znajdujących się w posiadaniu poszczególnych bibliotek, a także wizje i misje polskich bibliotek uczelnianych, w istotny sposób wpływają na kierunki działalności i rozwoju tych podmiotów. Profesjonalna działalność i ciągły, ukierunkowany rozwój wymaga zapewnienia odpowiednich środków finansowych. Działalność bibliotek akademickich jest finansowana głównie ze środków uczelni, ale biblioteki mogą ubiegać się także o zewnętrzne źródła finansowania. Najważniejszym donatorem krajowych środków pozauczelnianych przeznaczanych na rozwój bibliotek uczelnianych jest Ministerstwo Nauki i Szkolnictwa Wyższego, a środki europejskie wspomniane biblioteki mogą uzyskać w ramach krajowych i regionalnych programów operacyjnych. W przypadku wspomnianych bibliotek, środki krajowe przeznaczane są przede wszystkim na działania związane z utrzymaniem unikatowych w skali kraju zasobów bibliotecznych o istotnym znaczeniu dla nauki lub jej dziedzictwa, opracowywaniem naukowych zasobów bibliotecznych i udostępnianiem zasobów bibliotecznych w formie elektronicznej (MNiSW, 2016a). Natomiast środki europejskie wspomagają głównie budowę platform, udostępniających nieodpłatnie zasoby nauki w wersji elektronicznej (CPPC, 2016). Jak wspomniano, najważniejszym podmiotem wspierającym rozwój bibliotek akademickich ze środków krajowych w sposób ciągły i systematyczny, jest wspomniane wcześniej Ministerstwo odpowiedzialne za rozwój nauki i szkolnictwa wyższego. Zapewnia ono środki na działalność upowszechniającą naukę, definiowaną jako „realizacja zadań wspierających rozwój polskiej nauki przez upowszechnianie, promocję i popularyzację wyników działalności badawczo-rozwojowej, innowacyjnej i wynalazczej, w tym w skali międzynarodowej, a także zadań związanych z utrzymaniem zasobów o dużym znaczeniu dla nauki i jej dziedzictwa, nieobejmujących prowadzenia badań naukowych lub prac rozwojowych" (2016, MNiSWa). Zgodnie z aktualnym Rozporządzeniem Ministra Nauki i Szkolnictwa Wyższego z dnia 8 września 2016 r. w sprawie szczegółowych 
kryteriów i trybu przyznawania oraz rozliczania środków finansowych na działalność upowszechniającą naukę, przed przyznaniem środków bibliotece weryfikacji przez donatora podlega przede wszystkim znaczenie zbiorów bibliotecznych w skali kraju, ich wpływ na upowszechnianie nauki, w tym udział we współpracy krajowej lub międzynarodowej bibliotek naukowych w zakresie elektronicznych zasobów bibliotecznych. Ministerstwo analizuje także znaczenie przedsięwzięcia dla utrzymania, opracowania lub udostępniania zasobów bibliotecznych w postaci cyfrowej oraz metody utrzymania, opracowania oraz zakres udostępniania zasobów bibliotecznych w tej postaci (MNiSW, 2016b). Kryteria oceny stosowane przez omawianego donatora, decydujące o przyznaniu środków w ramach działalności upowszechniającej naukę, nawiązują w bezpośredni sposób do obszarów wsparcia środków europejskich przeznaczonych dla bibliotek. Środki unijne przeznaczone dla bibliotek akademickich pozostają $\mathrm{w}$ dyspozycji instytucji zarządzających i instytucji pośredniczących, czyli przede wszystkim Ministerstwa Rozwoju, Urzędów Marszałkowskich, Ministerstwa Kultury i Dziedzictwa Narodowego i Centrum Projektów Polska Cyfrowa. Natomiast środki, którymi dysponuje Ministerstwo Nauki i Szkolnictwa w celu wspierania działalności upowszechniającej naukę prowadzonej przez biblioteki, stanowią komplementarne uzupełnienie funduszy europejskich dedykowanych bibliotekom uczelnianym, zainteresowanym pozyskaniem zewnętrznego wsparcia finansowanego na swój rozwój.

\section{AKTYWNOŚĆ PROROZWOJOWA BIBLIOTEK AKADEMICKICH ZWIĄZANA Z POZYSKIWANIEM ŚRODKÓW POZAUCZELNIANYCH}

W artykule skoncentrowano się na wskazaniu kierunków i zakresu pozyskiwania środków zewnętrznych $w$ ramach działań na rzecz nauki i związanych $z$ upowszechnianiem nauki. W badaniu przyjęto perspektywę czasową obejmującą lata 2010-2015, gwarantującą możliwość poddania analizie i syntezie szerokiego zakresu danych. W celu ich pozyskania analizowano następujące dokumenty: Komunikat Ministra Nauki i Szkolnictwa Wyższego nr 17 z dnia 5 grudnia 2011 r. o przyznanych środkach finansowych na działalność wspomagającą badania w 2010 r. (MNiSW, 2010), Komunikat Ministra Nauki i Szkolnictwa Wyższego z dnia 29 marca 2012 r. o przyznanych środkach finansowych na działalność wspomagającą badania oraz na działalność upowszechniającą naukę w 2011 r. (MNiSW, 2012), Komunikat Ministra Nauki i Szkolnictwa Wyższego z dnia 18 marca 2013 r. o środkach finansowych przyznanych na działalność upowszechniającą naukę w 2012 r. (MNiSW, 2013), Komunikat Ministra Nauki i Szkolnictwa Wyższego z dnia 22 kwietnia 2014 r. o przyznanych środkach finansowych na naukę na finansowanie zadań z zakresu działalności upowszechniającej naukę (MNiSW, 2014), Wykaz podmiotów działających na rzecz nauki, którym przyznano 
środki finansowe w 2014 r. na finansowanie zadań z zakresu działalności upowszechniającej naukę (MNiSW, 2016e), Wykaz podmiotów działających na rzecz nauki, którym przyznano środki finansowe w 2015 r. na finansowanie zadań z zakresu działalności upowszechniającej naukę (MNiSW, 2016f), Wykaz podmiotów działających na rzecz nauki, którym w 2014 r. przyznano środki finansowe $\mathrm{w}$ ramach działalności upowszechniającej naukę dla bibliotek (MNiSW, 2016c), Wykaz podmiotów działających na rzecz nauki, którym w 2015 r. przyznano środki finansowe w ramach działalności upowszechniającej naukę dla bibliotek (MNiSW, 2016d). Badania w początkowej fazie związane były z weryfikacją załączników do wyżej wymienionych komunikatów oraz wykazów udostępnionych na podstawie prawa dostępu do informacji publicznej. We wspomnianych dokumentach zweryfikowano 6454 pozycje zawierające informacje o nazwie dofinansowanego zadania, nazwie podmiotu otrzymującego dofinansowanie i wysokości przyznanego dofinansowania, przy czym przyjęto założenie, że analiza uwzględnia kwoty dofinansowania przyznane $\mathrm{w}$ danym roku, na określone zadania realizowane $\mathrm{w}$ ramach poszczególnych projektów. Należy jednak wspomnieć, że podczas zbierania materiału badawczego nie udało się ustalić liczby podmiotów ogółem, które złożyły wnioski o przyznanie dofinansowania, ze względu na to, że przedmiotowe dane nie zostały zakwalifikowane przez ministerialnego donatora środków krajowych jako informacja publiczna. Przeprowadzone badania pozwoliły jednak na identyfikację ukierunkowanych obszarów działalności prorozwojowej bibliotek akademickich, określenie wysokości uzyskanych przez te podmioty środków z podziałem na wspomniane obszary oraz analizę środków przyznanych przez donatora na rozwój e-zasobów, a także wskazanie liczby bibliotek otrzymujących wsparcie w analizowanym okresie.

Badania dotyczące identyfikacji obszarów działalności prorozwojowej bibliotek w latach 2010-2015 wykazały, że wspomniane podmioty pozyskiwały środki na działalność związaną z pracami nad starymi drukami, konserwacją zbiorów, naukowymi bazami danych, opracowaniem zbiorów, czasopismami naukowymi, repozytoriami uczelnianymi, literaturą naukową działaniami promocyjnymi, konferencjami bibliotecznymi, retrokonwersją zbiorów, seminariami bibliotecznymi, systemami bibliotecznymi, udostępnianiem zbiorów, wyposażeniem stanowisk bibliotecznych dla osób z dysfunkcjami i digitalizacją zbiorów. Na tej podstawie zidentyfikowano zatem piętnaście obszarów działalności bibliotek akademickich finansowanych z krajowych środków zewnętrznych, co potwierdza jednoznacznie wielozadaniowa, różnorodną i zarazem uniwersalną funkcję bibliotek akademickich w strukturach organizacyjnych publicznych i niepublicznych szkół wyższych. Badania przeprowadzone w zakresie wysokości uzyskanych środków wykazały ich istotne zróżnicowanie w odniesieniu do poszczególnych obszarów działalności bibliotek. W latach 2010-2015 biblioteki akademickie 
pozyskały od donatora ministerialnego kwotę 14129 407,97 PLN na działania prorozwojowe. W tym na stare druki 421570,00 PLN, konserwację zbiorów 421 939,50 PLN, naukowe bazy danych 932 847,88 PLN, opracowanie zbiorów 1798 718,00 PLN, czasopisma naukowe 287 208,00 PLN, repozytoria uczelniane 1365 210,20 PLN, literaturę naukową 211 612,25 PLN, działania promocyjne 52 800,00 PLN, konferencje biblioteczne 134 568,00 PLN, retrokonwersję zbiorów 1715 314,00 PLN, seminaria biblioteczne 3 000,00 PLN, systemy biblioteczne 2397 662,74 PLN, udostępnianie zbiorów 1352 140,40 PLN, wyposażenie stanowisk bibliotecznych dla osób z dysfunkcjami 35 000,00 PLN i digitalizację zbiorów 2999 817,00 PLN. Prawie 89\% środków ogółem pozyskanych przez biblioteki akademickie na działalność prorozwojową w latach 2010-2015, dotyczyło finansowania digitalizacji zbiorów, systemów bibliotecznych, opracowywania, retrokonwersji i udostępniania zbiorów, dostępów do naukowych baz danych i repozytoriów uczelnianych. Pozostałe $11 \%$ środków ogółem pozyskanych przez biblioteki akademickie na działalność prorozwojową w latach 2010-2015, związanych było głównie z konserwacją woluminów (konserwacja zbiorów oraz konserwacja i opracowanie starych druków) i zakupem drukowanej literatury naukowej. Szczegółową strukturę wydatków bibliotek akademickich w okresie objętym badaniem przedstawia poniższy wykres.

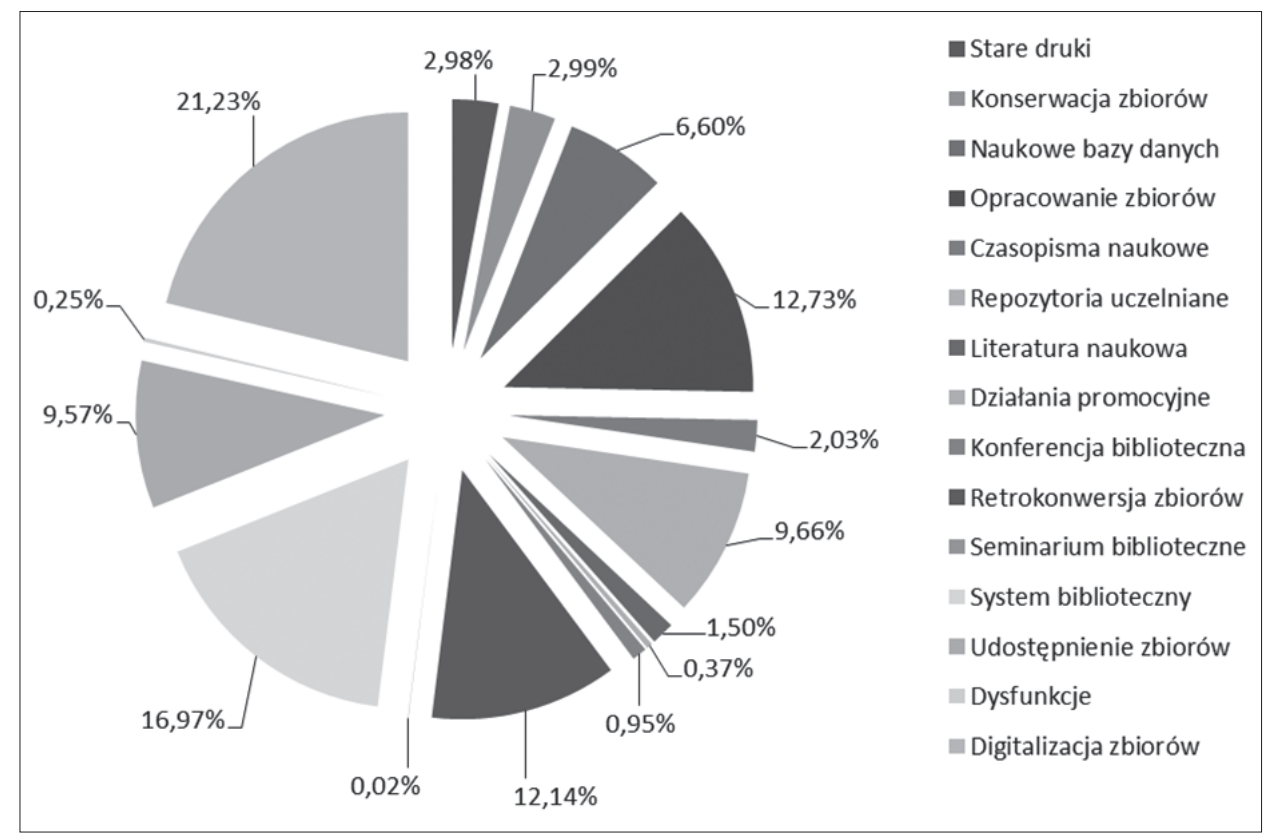

Wykres 1. Udział procentowy środków pozyskanych na poszczególne obszary działalności prorozwojowej bibliotek akademickich w środkach pozyskanych ogółem w latach 2010-2015

Źródło: Oprac. własne na podstawie badań. 


\section{DYNAMIKA PROCESU FINANSOWANIA DOSTĘPU DO ZASOBÓW ELEKTRONICZNYCH}

Warto zwrócić także uwagę na dynamikę finansowania działań prowadzących do zwiększenia dostępu do szeroko rozumianych zasobów elektronicznych w bibliotekach akademickich, obejmujących wsparcie systemów bibliotecznych, digitalizację zbiorów, repozytoria uczelniane i naukowe bazy danych. W przypadku systemów bibliotecznych donator w 2010 r. nie przyznał środków na ich zakup, ale już od 2011 r. wydatki na ten cel systematycznie rosły od 205 734,74 PLN aż do 1178 519,00 PLN w 2013 r., co stanowi największą kwotę ogółem przyznaną na rozwój zasobów elektronicznych w danym roku. Jednocześnie jest to prawie sześciokrotny wzrost wydatków w tym obszarze w okresie trzech lat. Jednak do 2015 r. wydatki związane z zakupem systemów bibliotecznych ponownie spadły osiągając sumę 111 776,00 PLN, co stanowi niewiele ponad 50\% środków na ten cel przyznanych przez podmiot wspierający w $2011 \mathrm{r}$. Dofinansowanie digitalizacji zbiorów przez ministerstwo odpowiedzialne za naukę charakteryzowało się podobnymi fluktuacjami, jak to miało miejsce $\mathrm{w}$ przypadku systemów bibliotecznych, a pierwsze wsparcie na działania digitalizacyjne w kwocie 58 500,00 PLN zostało przyznane w 2011 r. Najwięcej środków na omawiany obszar działalności bibliotek, tj. 941 278,00 PLN zostało przyznanych w 2013 r., co stanowi szesnastokrotny wzrost w odniesieniu do kwoty pierwszego przyznanego wsparcia. Jest to także druga największa kwota ogółem przyznana na rozwój zasobów elektronicznych w danym roku. Jednocześnie od 2012 do 2015 r. łączne dofinansowanie na działalność w obszarze digitalizacji zasobów nie spadło poniżej kwoty 472 160,00 PLN w skali roku. Największą dynamiką zmian charakteryzowało się jednak wsparcie przyznane w obszarze finansowania repozytoriów uczelnianych. W przypadku porównania wysokości pomocy przyznanej w 2011 r. wynoszącej 15 500,00 PLN, z kwotą wsparcia z 2013 r., tj. 612 219,00 PLN, możemy zaobserwować prawie czterdziestokrotny wzrost środków ogółem przyznanych przez donatora w analizowanym obszarze. Kwota wsparcia przyznana w 2013 r. to największa kwota ogółem przyznana na rozwój repozytoriów uczelnianych w badanym okresie. Jednocześnie od 2012 do 2015 r. wparcie na działalność w obszarze repozytoriów uczelnianych nie spadło poniżej kwoty 123 300,00 PLN w skali roku. Znaczną dynamika, ale już nie tak dużą jak w przypadku zmian w wysokości środków przyznanych na wsparcie repozytoriów uczelnianych, charakteryzowało się finansowanie przez donatora zakupu naukowych baz danych. Porównanie najniższej i najwyższej przyznanej kwoty na działania w obszarze dofinansowania baz danych, wskazuje na prawie dwudziestoczterokrotny wzrost sumy dofinansowania, w przypadku porównania dofinansowania z 2010 r. w kwocie 
15 750,00 PLN i z 2013 r. wynoszącego 375 466,18 PLN. Dodatkowo należy wspomnieć, że według analizowanych danych w 2010 r. nie przyznano wsparcia na systemy biblioteczne i digitalizację zbiorów, a w 2015 r. nie przyznano środków na zakup naukowych baz danych. Szczegółową strukturę zmian w wysokości dotacji na rozwój zasobów elektronicznych, w okresie objętym badaniem, przedstawia poniższy wykres.

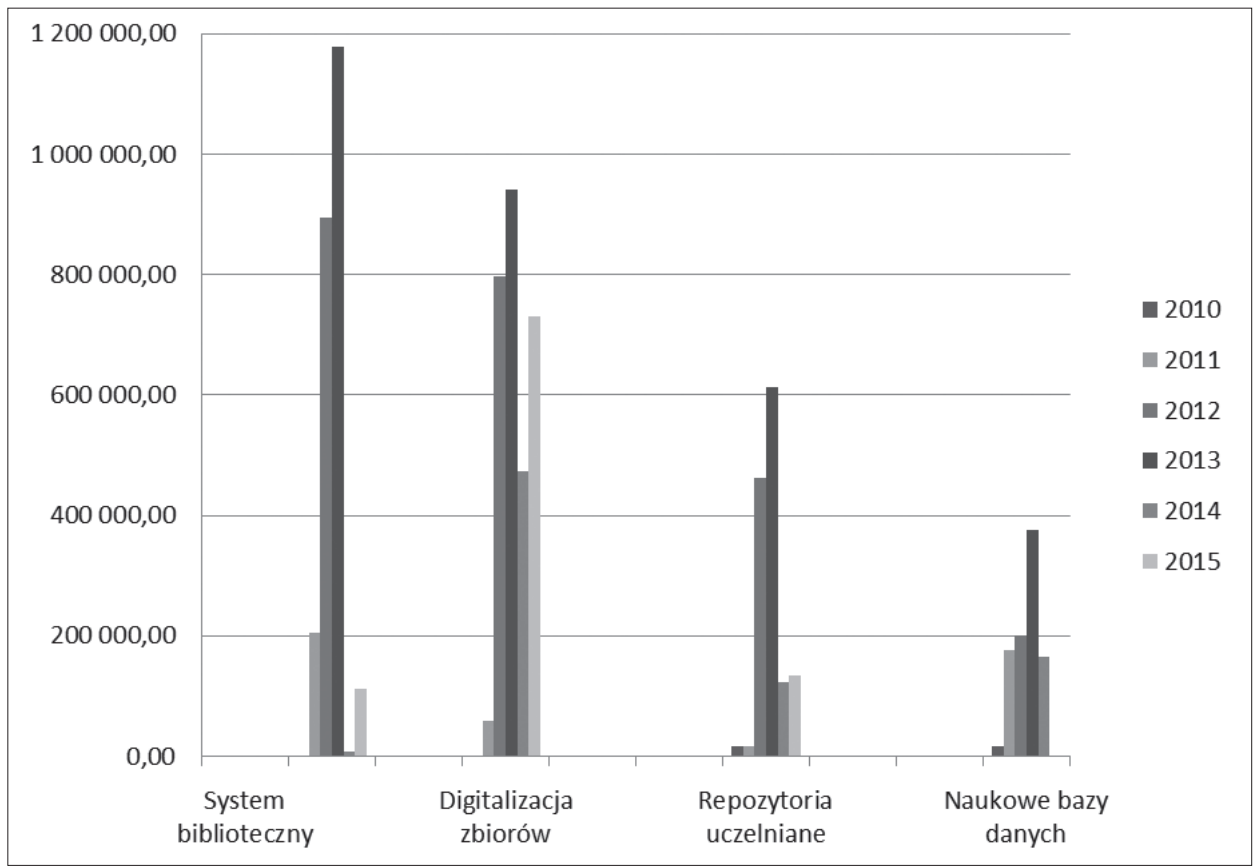

Wykres 2. Struktura dotacji przyznanych przez Ministerstwo Nauki i Szkolnictwa Wyższego na zwiększenie dostępu do zasobów elektronicznych w ramach działań na rzecz nauki i upowszechniania nauki w latach 2010-2015

Źródło: Oprac. własne na podstawie badań.

\section{KATEGORIE BIBLIOTEK AKADEMICKICH OTRZYMUJĄCYCH DOTACJE MINISTERIALNE}

Badania związane z liczbą podmiotów otrzymujących wsparcie w ramach działalności na rzecz nauki i upowszechniania nauki, pozwoliły na identyfikację sześćdziesięciu siedmiu podmiotów, dofinansowanych ze źródeł ministerialnych w latach 2010-2015. Grupa beneficjentów środków jest bardzo różnorodna i obejmuje przede wszystkim publiczne i niepubliczne szkoły wyższe. W jej składzie znalazły się państwowe wyższe szkoły zawodowe, uniwersytety, akademie, politechniki, Szkoła Główna Handlowa w Warszawie, Wyższa Szkoła Policji w Szczytnie, Wyższa Szkoła Wojsk 
Lądowych we Wrocławiu, wyższe seminaria duchowne i prywatne szkoły wyższe. Czternaście podmiotów prywatnego szkolnictwa wyższego pozyskało dofinansowanie na działania prorozwojowe bibliotek w wysokości 1331 519,60 PLN, co stanowi 9,42\% środków ogółem pozyskanych przez biblioteki akademickie na działalność prorozwojową w badanym okresie. Nie ulega więc wątpliwości, że większą skutecznością w pozyskiwaniu środków na działania prorozwojowe bibliotek wykazały się pięćdziesiąt trzy podmioty publicznego szkolnictwa wyższego. Uzyskały one dofinansowanie na kwotę 12797 888,37 PLN, co stanowi 90,58\% środków ogółem pozyskanych przez biblioteki akademickie na działalność upowszechniającą naukę $\mathrm{w}$ okresie objętym badaniem. Warto zwrócić uwagę na szczegółową strukturę publicznych szkół wyższych, których biblioteki uzyskały dofinansowanie na działania prorozwojowe, finansowane ze środków pozauczelnianych. Ponad 77\% wsparcia z ministerstwa finansującego rozwój nauki i szkolnictwa wyższego trafiło do bibliotek uniwersyteckich, a prawie $16 \%$ do bibliotek uczelni technicznych i medycznych. Pozostałe kilka procent środków ministerialnych zostało pozyskanych przede wszystkim przez akademie wychowania fizycznego i wyższe seminaria duchowne. Szczegółową strukturę udziału publicznych szkół wyższych w środkach pozyskanych na działania prorozwojowe bibliotek akademickich w okresie objętym badaniem przedstawia wykres 3 .

Szczegółowa analiza przeprowadzona w latach 2010-2015, pozwoliła ponadto na wskazanie podmiotów wyższego szkolnictwa publicznego (do których przyporządkowano seminaria duchowne) i wyższego szkolnictwa niepublicznego, które $\mathrm{w}$ danym roku pozyskały największą sumę środków od donatora ministerialnego. W przypadku publicznych szkół wyższych w 2010 r. najwyższą łączną kwotę wsparcia wynoszącą 71 102,50 PLN przyznano Wyższemu Seminarium Duchownemu Metropolii Warmińskiej Hosianum. Natomiast w 2011 r. najwyższą łączną kwotę dofinansowania na działania związane z upowszechnianiem nauki w wysokości 222 790,00 PLN otrzymał Uniwersytet Jagielloński. W latach 2012, 2013 i 2015 najwyższe łączne kwoty wsparcia pozyskał Uniwersytet Warszawski, które wyniosły w sumie 2047 456,00 PLN. Uniwersytet Łódzki w 2014 r. otrzymał największe łączne dofinansowanie na działania upowszechniające naukę w kwocie 301 800,00 PLN. Wśród podmiotów niepublicznego szkolnictwa wyższego w 2010 r., największe łączne wsparcie od ministerstwa odpowiedzialnego za naukę wynoszące 60 000,00 PLN, otrzymała Szkoła Wyższa im. Pawła Włodkowica, która powtórzyła takie osiągnięcie w 2012 r. z łączną kwotą 107 000,00 PLN. W 2011 r. największą kwotę dofinansowania na działania upowszechniające naukę, tj. 19 000,00 PLN otrzymała Akademia Humanistyczna im. Aleksandra Gieysztora. Największe łączne wsparcie od ministerstwa będącego donatorem w okresie badań, wynoszące 351 700,00 PLN, otrzymała Krakowska Akademia im. Frycza Modrzewskiego w 2013 r. 


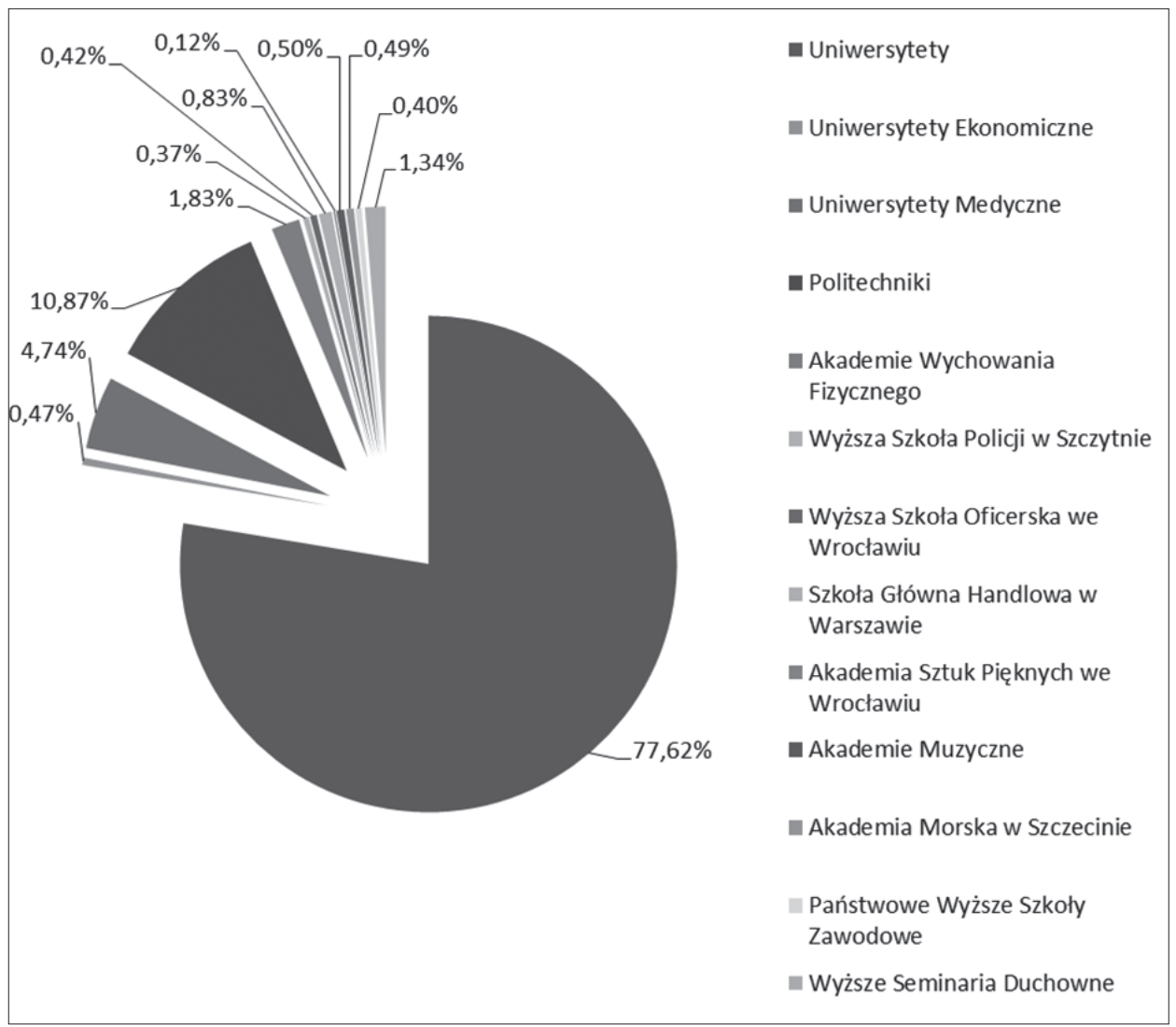

Wykres 3. Udział procentowy środków pozyskanych przez poszczególne typy publicznych szkół wyższych, w tym seminaria duchowne w środkach pozyskanych przez podmioty publicznego szkolnictwa wyższego ogółem na działalność upowszechniającą naukę w latach 2010-2015

Źródło: Oprac. własne na podstawie badań.

W 2014 r. nie przyznano wsparcia niepublicznej szkole wyższej, a w 2015 roku najwyższe łączne dofinansowanie wynoszące 196 200,00 PLN otrzymała Wyższa Szkoła Filologii Hebrajskiej.

\section{WNIOSKI}

Na podstawie przeprowadzonych badań można stwierdzić, że biblioteki akademickie, znajdujące się w strukturach publicznych i niepublicznych szkół wyższych, wykazały się umiejętnościami w zakresie pozyskiwania środków na działalność związaną z nauką i jej upowszechnianiem w piętnastu zidentyfikowanych obszarach ich rozwoju. Uwzględniając aktualne dane dotyczące bibliotek naukowych znajdujące się w Zintegrowanym 
Systemie Informacji o Nauce i Szkolnictwie Wyższym POL-on, ze wsparcia $\mathrm{w}$ badanym okresie $\mathrm{w}$ ramach działalności na rzecz nauki i upowszechniania nauki korzystało 67 z 393 (POLON, 2016) bibliotek, co stanowi zaledwie $17 \%$ podmiotów bibliotecznych uwzględnionych przez ten system. Objęte badaniem biblioteki w okresie 2010-2015 pozyskiwały średnioroczną kwotę wsparcia na działania prorozwojowe na poziomie 2354 901,33 PLN, przypadającą na wszystkie podmioty objęte wsparciem $\mathrm{w}$ danym roku, co jest kwotą stosunkowo niską. Wśród podmiotów ubiegających się o wsparcie ministerialne na działalność związaną z nauką i jej upowszechnianiem $\mathrm{w}$ analizowanym okresie, największą skutecznością $\mathrm{w}$ pozyskiwaniu przedmiotowych środków w skali roku wykazały się Uniwersytet Warszawski, Uniwersytet Łódzki i Uniwersytet Jagielloński, jako reprezentanci szkół wyższych sektora publicznego. Natomiast wśród podmiotów prywatnego szkolnictwa wyższego najlepszymi wynikami w pozyskiwaniu środków ministerialnych na działalność biblioteczną w skali roku legitymują się Krakowska Akademia im. Frycza Modrzewskiego, Wyższa Szkoła Filologii Hebrajskiej i Szkoła Wyższa im. Pawła Włodkowica. Jednocześnie badania wskazują na bardzo silny trend w działalności bibliotek związany z przygotowaniem i udostępnieniem zasobów w postaci elektronicznej. Potwierdza to bardzo wysoki udział finansowania działań ukierunkowanych na tworzenie e-zasobów we wszystkich rodzajach dofinansowanych działań, w tym związanych z konserwacją i starodrukami. Przedmiotowy trend był wyraźnie wspierany przez dotacje ministerialne związane $z$ upowszechnianiem nauki, szczególnie w latach 2012-2013, kiedy nastąpił prawie czterdziestokrotny wzrost środków dotacyjnych ogółem przyznanych na rozwój repozy toriów uczelnianych, w porównaniu do roku, kiedy przyznano najniższą dotację ogółem na ten cel. Natomiast najmniejszą dynamiką charakteryzowało się wsparcie zakupu systemów bibliotecznych, które w latach 2012-2013 wzrosło zaledwie sześciokrotnie, w porównaniu do 2011 r., kiedy pierwszy raz przyznano dotację ministerialną na ten cel. Z całym przekonaniem można zatem stwierdzić, że biblioteki pozyskują środki zewnętrzne na działania prorozwojowe w określonych obszarach swojej działalności, a największym doświadczeniem i skutecznością w tym zakresie legitymują się biblioteki znajdujące się w strukturach dużych publicznych uczelni wyższych reprezentowanych przez uniwersytety. W celu zwiększenia skuteczności bibliotek publicznych i prywatnych szkół wyższych w pozyskiwaniu środków ministerialnych, zasadne wydaje się podjęcie wspólnych działań całego środowiska bibliotekarskiego, zmierzających do uzyskania przez bibliotekarzy praktycznej wiedzy związanej z pozyskiwaniem i realizacją projektów bibliotecznych finansowanych ze środków zewnętrznych. Działania takie jak szkolenia, seminaria i konferencje, związane z problematyką projektową powinny skutkować zwiększeniem liczby bibliotek otrzymujących wsparcie pozauczelniane, 
realizacją wspólnych projektów bibliotecznych wykraczających poza granice jednego miasta lub województwa. Powinny prowadzić także do przygotowania w najbliższej przyszłości profesjonalnej grupy „bibliotekarzy projektowych", zapewniających swoim jednostkom organizacyjnym źródło dodatkowych dochodów, przeznaczanych na finansowanie działań prorozwojowych. Realizacja tych założeń przyczyni się bez wątpienia do wykreowania spójnej infrastruktury bibliotek akademickich wszystkich typów szkół, dostępnej zarówno dla środowiska uczelnianego, jak i otoczenia społeczno-gospodarczego, która będzie skutecznie wykorzystywana w rozwoju społeczeństwa opartego na wiedzy.

\section{BIBLIOGRAFIA}

CPPC (2016). Informacja o konkursie na dofinansowanie projektów w ramach Poddziałania 2.3.1 Cyfrowe udostępnienie informacji sektora publicznego ze źródeł administracyjnych i zasobów nauki (typ II projektu: cyfrowe udostępnienie zasobów nauki) [online]. Centrum Projektów Polska Cyfrowa; [dostęp: 10.10.2016]. Dostępny w WWW: <https://cppc.gov.pl/programy/popc-2/popc/popc_2-3-1_nauka_2016/>.

MNiSW (2010). Dziennik Urzędowy Ministra Nauki i Szkolnictwa Wyższego nr 4, pozycja 101. Warszawa, dnia 30 grudnia 2011 r. [online]. Ministerstwo Nauki i Szkolnictwa Wyższego; [dostęp: 20.10.2016]. Dostępny w WWW: <http://www.nauka.gov.pl/g2/oryginal/2013_05/bd6c5715d7b34fd10e06c6ab8510f1b4.pdf>.

MNiSW (2012). Dziennik Urzędowy Ministra Nauki i Szkolnictwa Wyższego, pozycja 26. Warszawa, dnia 17 kwietnia 2012 r. [online]. Ministerstwo Nauki i Szkolnictwa Wyższego; [dostęp: 20.05.2016]. Dostępny w WWW: <http://www.nauka.gov.pl/g2/oryginal/2013_05/4879ec9f841333a4d56747b1192ec327.pdf >.

MNiSW (2013). Dziennik Urzędowy Ministra Nauki i Szkolnictwa Wyższego, pozycja 25. Warszawa, dnia 29 kwietnia 2013 r. [online]. Ministerstwo Nauki i Szkolnictwa Wyższego; [dostęp: 26.05.2016]. Dostępny w WWW: <http://www.nauka.gov.pl/g2/oryginal/2013_05/3cdadab448f2b8731028c86c49552da2>.

MNiSW (2014). Komunikat Ministra Nauki i Szkolnictwa Wyższego z dnia 22 kwietnia 2014 r. o przyznanych środkach finansowych na naukę na finansowanie zadań z zakresu działalności upowszechniajacej naukę [online]. Ministerstwo Nauki i Szkolnictwa Wyższego; [dostęp: 02.06.2016]. Dostępny w WWW: <http://www.bip.nauka.gov.pl/g2/oryginal/2014 _04/157177897273175a3992c46b407027b9.pdf>.

MNiSW (2016a). Działalność upowszechniająca naukę [online]. Ministerstwo Nauki i Szkolnictwa Wyższego; [dostęp: 05.08.2016]. Dostępny w WWW: <http://www.nauka.gov. $\mathrm{pl} /$ dzialalnosc-upowszechniajaca-nauke/>.

MNiSW (2016b). Rozporzadzenie Ministra Nauki i Szkolnictwa Wyższego z dnia 8 września 2016 r. w sprawie szczegółowych kryteriów i trybu przyznawania oraz rozliczania środków finansowych na działalność upowszechniająca naukę [online]. Ministerstwo Nauki i Szkolnictwa Wyższego; [dostęp: 17.10.2016]. Dostępny w WWW: <http://dziennikustaw. gov.pl/DU/2016/1514>.

MNiSW (2016c). Wykaz podmiotów działających na rzecz nauki, którym w 2014 r. przyznano środki finansowe w ramach działalności upowszechniajacej naukę dla bibliotek. Warszawa: 
dokument uzyskany na podstawie dostępu do informacji publicznej z 8 kwietnia 2016 r. Pismo o sygnaturze BM.162.20.2016.

MNiSW (2016d). Wykaz podmiotów działajacych na rzecz nauki, którym w 2015 r. przyznano środki finansowe w ramach działalności upowszechniajacej naukę dla bibliotek. Warszawa: dokument uzyskany na podstawie dostępu do informacji publicznej z 8 kwietnia 2016 r. Pismo o sygnaturze BM.162.20.2016.

MNiSW (2016e). Wykaz podmiotów działających na rzecz nauki, którym przyznano środki finansowe w 2014 roku na finansowanie zadań z zakresu działalności upowszechniajacej naukę. Warszawa: dokument uzyskany na podstawie dostępu do informacji publicznej z 21 lipca 2016 r. Pismo o sygnaturze BM.WKN.162.25.2016.3.KKF.

MNiSW (2016f). Wykaz podmiotów działających na rzecz nauki, którym przyznano środki finansowe w 2015 roku na finansowanie zadań z zakresu działalności upowszechniajacej naukę. Warszawa: dokument uzyskany na podstawie dostępu do informacji publicznej z 21 lipca 2016 r. Pismo o sygnaturze BM.WKN.162.25.2016.3.KKF.

POLON (2016). Biblioteki naukowe w systemie POL-on [online]. Zintegrowany System Informacji o Nauce i Szkolnictwie Wyższym; [dostęp: 04.08.2016]. Dostępny w WWW: <https://polon.nauka.gov.pl/opi/aa/biblioteki;jsessionid=AE57437AB488894FF21E2E5F40AD1463.NwsProdB?execution=e1s1>.

Artykuł wptynąt do Redakcji w wersji poprawionej 20 stycznia 2017 r.

\author{
JACEK WILLECKI \\ The Library of Poznan University of Technology \\ Department of Reference Services \\ e-mail: jacek.willecki@put.poznan.pl
}

\title{
PRO-GROWTH ACTIVITIES OF ACADEMIC LIBRARIES RELATED \\ TO SCIENCE AND ITS DISSEMINATION AS FINANCED WITH THE FUNDS OF THE MINISTRY OF SCIENCE AND HIGHER EDUCATION IN THE YEARS 2010 TO 2015
}

KEYWORDS: Pro-growth activities of libraries. Dissemination of science by libraries. Financing the development of higher education libraries. Activities of libraries in the years 2010 to 2015.

ABSTRACT: Thesis/Objective - this article is aimed at: identifying the areas of the progrowth activities of the academic libraries related to science and its dissemination as financed with the funds from the Ministry of Science and Higher Education, specifying the amount of resources obtained from this Ministry by the libraries of public and non-public univer- 
sities including funds for the development of e-resources and discovering the number of libraries which receive the pro-growth support for the activities in question. Research methods - the synthesis and analysis of the ministerial messages and lists of data concerning the funds allocated to the science-supporting activities. Results and conclusions - The author found the academic libraries to be active in fifteen areas, analyzed the structure of the funds they received and indicated types of public universities which were highly effective in obtaining resources for the activities related to science dissemination in the years 2010 to 2015 . 